\title{
RESPONSE
}

\section{Response to Kurt Cardinal Koch}

\author{
Karla Suomala, Luther College
}

A Response to Cardinal Kurt Koch's October 30, 2011 Keynote Address

at Seton Hall University during the $10^{\text {th }}$ Annual Meeting of the

Council of Centers on Christian-Jewish Relations

\section{Introduction}

In his statement on Jewish-Catholic dialogue, Kurt Cardinal Koch grounds his understanding of the relationship between Jews and Christians in both an historical perspective which emphasizes the role of ideological conflict and hostility between Jews and Christians from the very earliest stages of Christianity as well as in a theological perspective by which Jews and Christians are bound together as the one people of God under one covenant. He characterizes the relationship between Jews and Christians as one both of mutual responsibility for a tragic history as well of mutual obligation to forge a new relationship out of a shared eschatological vision. In this response, I would like to focus my comments on the particular historical model that the Cardinal uses to frame his argument and then to consider the challenges to maintaining the integrity and independence of each tradition posed by the theological framework Koch employs.

\section{"Parting of the Ways" Model}

In his opening paragraph, Cardinal Koch traces the long estrangement between Jews and Christians to the emergence of Christianity, describing the separation between the two traditions as the first split and the "primal rift" in the church's history. While he admits that current scholarship points to a longer process of separation than was previously supposed, his use of phrases such as "very beginning," "early," and "primal" along with his designation of discrete institutions such as "church" and "synagogue" from the first century suggests that the conflict between Jews and Christians was an inevitable, perhaps even necessary, part of their development. ${ }^{1}$ Citing Cardinal Ratzinger, he goes on to suggest that the relationship between the "blind and obstinate mother" and the "unnatural daughter" was doomed from the outset, eventually disintegrating to the point where even the memory of a family relationship was lost. ${ }^{2}$ Later in the document when Cardinal Koch states that

...Pope Benedict XVI rightly concluded from [the destruction of the Temple in $70 \mathrm{CE}$ ] that there were as a consequence two responses to this situation, or more precisely, two new ways of reading the Old Testament after the year 70, namely the Christological exegesis of the Christians and the rabbinical exegesis of that form of Judaism which arose after the destruction of the temple...

\footnotetext{
${ }^{1}$ Kurt Cardinal Koch, "Theological Questions and Perspectives in Jewish-Catholic Dialogue," 1. Remarks with some minor changes made at Seton Hall University in South Orange, NJ as its eighteenth Annual Msgr. John M. Oesterreicher Memorial Lecture and also as the keynote address for the tenth annual meeting of the Council of Centers on Jewish-Christian Relations.

${ }^{2}$ lbid.
} 
he reaffirms his sense of how quickly Christianity and Judaism emerged as two separate traditions, responding in two unrelated ways to the same sacred text. ${ }^{3}$ In this reconstruction of the first century, often referred to as the "parting of the ways," Jews and Christians separated early on, quickly becoming distinct religious traditions that "developed in relative isolation from one another" and whose interactions were "limited, almost wholly, to polemical conflict and mutual misperception."4

While first articulated in the late $19^{\text {th }}$ century, this "partings" model really only began to take hold in academic and ecclesiastical circles after the Shoah as scholars and clergy began to question the consequences of supersessionism, the idea that Christians had replaced Jews as God's chosen people. Standing at the "centre of Christianity's understanding of its relationship to the Jewish people from antiquity..." new life was breathed into the supersessionist framework by leading German Protestant intellectuals such as Kant, Schleiermacher, and Harnack who rearticulated it for a post-Enlightenment world as the triumph of Christian universalism and humanism over Jewish particularism and tribalism. ${ }^{5}$ The "partings model," by contrast, was appealing, in that instead of the harsh displacement of one tradition by the other, it allows for both Judaism and Christianity to be approached as authentic religions in their own right, with equally strong links to the biblical and Second Temple Jewish heritage that they share. As such, this model proves palatable to Jews and Christians alike; the former can affirm the Jewish origins of Christianity even as they deny any Christian influence on the development of classical rabbinic Judaism, while the latter can claim a profound continuity with pre-Christian Jewish history even as they affirm the essential originality of the (Gentile) Christian message. ${ }^{6}$

For precisely these reasons, as well as the fact that it offers "a reassuringly ecumenical etiology of the religious differences between present-day Christians and Jews," Cardinal Koch is not alone in in using this model to begin his discussion of Jewish Christian relations. ${ }^{7}$

\section{Challenges to the "Partings" Model}

Even though the "partings" metaphor served as a much-needed corrective to the supersessionist model by taking into account a wider range of theological, historical, and literary perspectives, it has in many ways become outdated. Looking more closely at the origins of Christianity and its relationship to Judaism in recent decades, it has become clear to many scholars that the "literary and archaeological data...attest a far messier reality than this unilinear spatial metaphor allows." As a result, the "partings" model has been challenged on a number of different fronts and many newer models have been proposed. So, for example, in contrast to both the supersessionist and "partings" models, which generally assume a mother-daughter relationship between Judaism and Christianity, a number of scholars, including Hayim Perlmuter, Alan Segal, Gabriele Boccaccini, Israel Yuval, and Mary Boys, have replaced the mother-daughter metaphor for the relationship as one of siblings or even fraternal twins. This strand of scholarship lends itself to thinking about Judaism and Christianity as religious traditions that developed out of a common

3 Ibid., Part 2a.

${ }^{4}$ Adam H. Becker and Annette Yoshiko Reed, eds., "Introduction: Traditional Models and New Directions," in The Ways That Never Parted: Jews and Christians in Late Antiquity and the Early Middle Ages (Minneapolis: Fortress Press, 2007) Kindle Edition.

${ }^{5}$ R. Kendall Soulen, "Supercessionism," in A Dictionary of Jewish-Christian Relations, ed. Edward Kessler et al. (Cambridge, UK: Cambridge University Press, 2008) 413-414.

${ }^{6}$ Becker and Reed.

${ }^{7}$ Ibid.

${ }^{8}$ lbid. 
ancestor, proto- or biblical Judaism. Within this sibling framework the early centuries of the common era are interpreted in such a way that Christianity and Judaism as we understand them today emerged closer in time to each other, out of the same "stuff," and under similar circumstances.

In addition to new metaphors for the familial bonds between Jews and Christians, scholars have also extended the timeline for a "parting of the ways" far beyond the first century, into the second and third, and even as far as the fifth. This is in part due to studies that problematize the uniformity of Christianity and Judaism in the early centuries of the common era, pointing out that it is probably more accurate to speak of Christianities and Judaisms rather than two stable monolithic traditions. In fact, it is still not clear when the distinct trajectory or constellation of identity markers that we read onto the Judaism and Christianity of today appeared and came to dominate the religious landscape of the traditions. All of this points to a more gradual development of discrete religious traditions in which the beliefs, practices, and interpretive methods, as well as the relationships between Jews and Christians, were likely more varied, and in which the identities of both the communities and their members were more nuanced than we have previously imagined. This "new" picture of Jewish-Christian relations leads Annette Yoshiko Reed and Adam Becker, in The Ways That Never Parted: Jews and Christians in Late Antiquity and the Early Middle Ages, to pose even more far-reaching questions: did a full and complete parting of the ways ever happen? Did Judaism and Christianity ever, in fact, become entirely distinct from and independent of each other $?^{9}$ Perhaps they have had points of intersection or connection all along, shaping and influencing each other in ways that are often more localized and not necessarily as obvious.

Jews, Christians, and Power

While the "partings" model has been significant in helping Christians (in particular) see Judaism as an authentic and living tradition apart from Christianity, it can at the same time give the impression that the historical relationship between Jews and Christians was more symmetrical than it actually was. What is often left unstated is the dramatic shift in the fortunes of Christianity visà-vis the Jews under the Emperor Constantine, and the eventual designation of Christianity as the official religion of the Roman Empire by the Emperor Theodosius I in 380 CE. The consequences of this shift in the balance of power as well as the growth in the numbers of Christians which accompanied it can hardly be overstated: from that point on, Jews in Christian lands were at a disadvantage economically, politically, socially, and religiously. Within 250 years of Constantine's accession to power, as Jacob Rader Marcus points out, Judaism could no longer legally "grow" through proselytization, and Jews, among other things, could no longer hold particular public offices, testify against Christians in court, enter into marriages with Christians, or build new synagogues. ${ }^{10}$

So when Koch characterizes the historical relationship between Jews and Christians as one of "great strain and hostility which has in many cases unfortunately led to anti-Jewish attitudes involving outbreaks of violence and pogroms against the Jews," he overlooks the deeply institutional quality of the hostility that emerged among Christians toward Jews. ${ }^{11}$ The restriction of Jewish rights, opportunities, and practices was much more systematic than Koch's description of "anti-Jewish attitudes involving outbreaks of violence..." indicates. And even though Koch

\footnotetext{
${ }^{9}$ lbid.

${ }^{10}$ Jacob Marcus, The Jew in the Medieval World: A Sourcebook, 315-1791 (New York: JPS, 1938) 3-7.

${ }^{11}$ Koch, Part 1.
} 
maintains that the Catholic Church has never had an official mission to the Jews, the coercive Catholic Christian initiatives in this arena are overlooked, especially the waves of forced conversions that occurred in the Middle Ages. While not perhaps formally endorsed by the Church, these actions were conducted by members of the Church. By the close of the medieval period, when policies and coercive action had failed to solve the Jewish "problem," England, Spain, and Portugal became the first European countries to issue decrees of expulsion, forcing their Jewish populations to flee. "It should come as no surprise that the worst allegations of Jewish antisocial tendencies were devised [during these tumultuous times], including the notorious blood libel and allegations that the Jews poisoned the wells," writes Michael Frassetto. ${ }^{12}$

Rather than exploring the consequences of such an imbalance in power for Jewish-Christian relations, Koch jumps immediately to the $20^{\text {th }}$ century where he continues to use the "partings model" as a lens through which to interpret the Shoah. Indicating that "Hostility towards the Jews reached its lowest nadir in the history of Europe with the mass murder of European Jews," he locates the Shoah at the end of a trajectory that began in the first century, giving the impression that the Shoah was the unfortunate product or result of a long, mutual hostility between Christians and Jews, one for which the Jews must perhaps bear part of the blame. ${ }^{13}$

This particular construction of the Shoah is problematic for many other reasons, including the fact that it does not work within the framework that Cardinal Koch has chosen to use. On the one hand he has suggested that the mutual hostility between Jews and Christians was brought to a head in the Shoah; on the other, he says that the "Shoah cannot and should not however be attributed to Christianity as such," and that it was instead "led by a godless, anti-Christian and neopagan ideology." These seem to be mutually exclusive rationales for the Shoah, unless Koch sees the National Socialists as an independent heir to and participant in the hostility of Christians toward Jews (which may be the case). At any rate, his statement that the "Shoah cannot be... attributed to Christianity" appears to be grounded in efforts to protect the Church rather than to acknowledge its responsibility for the extermination of one-third of the world's Jews. ${ }^{14}$ This is disheartening for both Jews and Christians, especially in the wake of Nostra Aetate - the 1965 declaration which marked a turning point in Catholic-Jewish relations, shaped subsequent Catholic statements on the Holocaust, and had a deep impact on Protestant Christian communities' relationships to the Jewish people. It was only after the publication of Nostra Aetate that many Protestant churches in North America began to make their own statements about JewishChristian relations and in doing so acknowledged the responsibility of Christians and Christianity for the Holocaust.

In yet a further step, Cardinal Koch goes on to claim that Christianity was, like Judaism, a victim of the Shoah, and even its ultimate target. Citing the Goebbels diaries, Koch asserts that "Hitler hated Christianity just as much as Judaism, and...saw in Catholicism above all the virtual Trojan Horse of Judaism within Christianity" and that the Shoah "intended to annihilate not only Judaism but also the Jewish heritage in Christianity..." 15 This view fails to emphasize that the consequences of the Holocaust for Jews far outweighed those for Christians; it overlooks the fact that while Hitler may have hated Christianity, he chose to kill Jews. As John Pawlikowski notes, "No reputable scholar on the Holocaust would deny its neo-pagan roots nor its fundamental opposition to all religious perspectives. But equally reputable scholars, and I count myself in this

\footnotetext{
${ }^{12}$ Michael Frassetto, "Introduction," in Christian attitudes toward the Jews in the Middle Ages : a casebook, ed. Michael Frassetto (New York \& London: Routledge, 2007) xiv-xv.

${ }^{13}$ Koch, Part 1.

14 Ibid.

${ }^{15}$ Ibid.
} 
category, would also insist on surfacing the Holocaust's links with classical antisemitism. The Holocaust succeeded in a culture that supposedly was deeply impacted by Christian values for centuries." 16

\section{New Questions}

One of the outcomes of the articulation of new historical frameworks for understanding JewishChristian relations, beginning with the "partings" model and including the others which developed later, was the need to develop new theological models to accompany them. As a result, scholars and clergy alike returned to notions of promise and covenant with an intensity not seen since the days of Paul! If there was no supersession over or replacement of Jews by Christians, but rather a split or gradual emergence and more ambiguous separation of two authentic traditions which we call Christianity and Judaism today, then, as Richard Lux asks, should we "speak of multiple, but now related covenants, or is our relationship better characterized by considering there to be one covenant newly defined?" And if there is just one covenant, "how do Christianity and Judaism retain their individual distinctiveness and integrity?"17

Transitioning from the historical background of Jewish-Christian relations to the theological present, Cardinal Koch states that "We Christians must therefore honestly deplore the fact that only the unprecedented atrocity of the Shoah was able to effect a real turning point in thinking." ${ }^{18}$ In the same way that he depicted a "primal rift" between Judaism and Christianity as inevitable if not necessary, it almost seems as if the Shoah was the only possible means of changing the course of nearly 2,000 years of separation. At any rate, for Koch this "turning point" brought about a transformation in Jewish-Christian relations, revealing for the first time (or uncovering what had long been buried) the profound and unique theological connection between Jews and Christians. From this "groundbreaking discovery," the Church was able recognize the reciprocal relationship between Judaism and Christianity, in that each required the existence of the other in order to be complete or whole. ${ }^{19}$ The importance of the bond for both Jews and Christians, then, necessitates continued dialogue for the sake of maintaining the relationship, developing a more profound mutual understanding, and obtaining a common eschatological vision.

\section{"One Covenant, One People" Model}

Following in the footsteps of both John Paul II and Benedict, Koch aligns himself within Lux's second option, "one covenant newly defined," to argue that "For the Christian faith it is axiomatic that there can only be a single covenant history of God and humanity" in which Jews and Christians constitute the one people of God. ${ }^{20}$ Despite the fact that Nostra Aetate apparently permits two covenants, one for Jews and one for Christians, this idea has not been universally embraced by Catholics. Working from a strictly "one covenant, one people" model, Koch goes on to consider the challenge of maintaining such a connection when Jews and Christians live "in two parts in a state of division." ${ }^{21}$ In spite of the obstacles, though, Koch maintains that the bond between

\footnotetext{
${ }^{16}$ John Pawlikowski, O.S.M., "Pope Benedict XVI on Jews and Judaism: Retreat or Reaffirmation," The Glasmacher Lecture, Fall 2008, University of St. Paul, Ottawa, Ontario, Canada, accessed February 28, 2012, http://www.jcrelations.net/Pope_Benedict_XVI_on_Jews_and_Judaism_Retreat_or_Reaffirmation.2992.0.html.

${ }^{17}$ Richard Lux, The Jewish people, the Holy Land, and the state of Israel: a Catholic view (Mahwah, NJ: Paulist Press, 2010) 29.

18 Koch, Part 1.

19 lbid., Part 2d.

${ }^{20}$ Ibid., Part 2b.

${ }^{21}$ Ibid., Part 2c.
} 
the two is unique, continuous, and enduring. Since significant debate and scholarship have been focused on the development as well as critique of various covenantal models that best represent the theological dimension of the Jewish-Christian relationship; I want to focus instead on the problems that arise out of Koch's particular framing of the theological structure in which he places both Judaism and Christianity.

On the surface, the Cardinal repudiates supersessionism or replacement theology pointing out that they are both "scarcely represented today," but on closer examination he speaks from the vantage point of a certain Christian superiority vis-à-vis Judaism. Citing John Paul II, Koch affirms that 'The Jewish religion is not something 'extrinsic' to us but in a certain way is 'intrinsic' to our own religion." ${ }^{2}$ While clearly an attempt to articulate the idea that Judaism and Christianity are connected at a fundamental level, the statement can also intimate that Judaism does not really have an independent status with respect to Christianity but rather functions as a structural element which upholds Christianity. This later possibility is consistent with Koch's historical views on the Shoah as a neo-pagan attack on Christianity by means of Judaism and the Jewish people. Judaism appears in this supporting rather than equal role in a number of other passages, including Koch's discussions of both the New Testament and the New Covenant and the functions of each with respect to their older (Jewish) counterparts.

Under the subheading, "The New Testament as fulfilment, not substitution for the Old One," Koch takes up the relationship of the New Testament to the Old Testament. ${ }^{23}$ While fulfillment is more positive than substitution which is reflected in the Marcionite position that Koch decries, the Old Testament is nevertheless depicted as incomplete on its own terms, a position Jews would certainly find problematic. Koch himself recognizes the difficulties inherent in 'fulfillment' language, noting that "This Christological exegesis can easily give rise to the impression that Christians consider the New Testament not only as the fulfillment of the Old but at the same time as a substitution for it." ${ }^{24} \mathrm{He}$ only partially corrects the potential for misunderstanding when he indicates that "this impression can only be correct in a limited sense..." ${ }^{25}$ Not explaining what the 'limited sense' might be at this point, he moves on to suggest that since the Jewish people, too, were "compelled to adopt a new reading of the Old Testament after the catastrophe of the destruction of the Second Temple in the year 70," the Old Testament was incomplete and needed fulfillment in their eyes as well. ${ }^{26}$ The ancient rabbis, however, never viewed the Mishnah and the Talmudim (Palestinian and Babylonian) as reinterpretations or re-readings of the Old Testament. These texts instead constituted Oral Torah, a different kind of revelation altogether that, while standing alongside the Written Torah, could be read independently of it as well.

It is perhaps in other portions of the document that we can begin to understand what Koch meant when he suggested that the New Testament could be understood as both fulfillment and substitution of the Old in only a limited sense, when he assigns, in a variety of different ways, a superior role to the (Christian) New Testament over and against the supporting role played by the (Jewish) Old Testament. In one instance, he cites Cardinal Ratzinger who said that the Jewish people "must remain as the first proprietors of Holy Scripture with respect to us, in order to establish a witness to the world." ${ }^{27}$ In another, Koch says that "Jesus' proclamation represents

\footnotetext{
22 Ibid., Part 2.

${ }^{23}$ lbid., Part $2 a$.

24 Ibid.

25 Ibid.

26 Ibid.

27 Ibid., Part 2d.
} 
'the true meaning of the Jewish faith in God itself' and Christianity remains 'bound to this point of departure."'28

This same assertion of Christianity's superiority also runs through Koch's discussion of covenant when he indicates that "The New Covenant is therefore neither the annulment nor the replacement of the Old Covenant," but rather the "surpassing affirmation and fulfilment of the Old." 29 There is no sense in this formulation that the covenant made by God with Abraham can stand alone or is sufficient in and of itself. In fact, says Koch, "We Christians are...convinced that through the new covenant the Abrahamic covenant has obtained that universality for all peoples which was of course originally intended." ${ }^{30}$ Interestingly, Koch points to the Abrahamic covenant rather than the more usual Mosaic covenant in which form it received its fullest expression. The bottom line is that the old covenant was able to reach its full potential only in and through the New Covenant which exceeded it in scope.

Judaism on Its Own Terms

As we have seen, some of the challenges inherent in the "one covenant, one people" model involve maintaining the distinctiveness and full integrity of both Judaism and Christianity. While some Jewish scholars, such as Michael Signer, have contributed significantly to the covenantal discussion, much of the conversation has been driven by Christian theologians like Cardinal Koch who are deeply troubled by the historical relationship between Jews and Christians, and passionately concerned about reconceptualizing the terms the relationship between them. While this is certainly important, the fairly one-sided impetus often results in formulations that tend to emphasize the needs and perspectives of Christians as opposed to Jews. What can emerge are statements that demonstrate a relative disinterest in (or lack of knowledge about) Judaism as a lived and vital religious tradition apart from Christianity and in the concerns and perspectives that the Jewish people might bring to dialogue with Christians.

Koch's emphasis on the mutual need of Christians and Jews for each other may be overstated in that it is never entirely clear that Judaism needs Christianity in the same way that Christianity purports to need Judaism. In one problematic example, Koch uses a "thorn in the flesh" image that evokes the crucifixion of Jesus to say that:

...Jews and Christians can each fulfill a reciprocal service toward the respective faith of the other. Where it remains true to its divine calling, Judaism is and remains a thorn in the flesh of Christians, in that it calls Christians to remember the experience of unredeemedness of the world... On the other hand, where the Christian church remains true to its divine mission, it is and remains a thorn in the flesh of Judaism, in that it bears witness to the already bestowed reconciliation of God with mankind, without which there can be no well-founded hope for redemption. ${ }^{31}$

Serving both as a reminder to Christians of "unredeemedness" in the world while at the same time needing to be constantly reminded that only through Christianity is there redemption, Judaism and the Jewish people are relegated to roles which are not necessarily grounded in true mutuality or a positive necessity. One almost gets the impression that the statement could be

\footnotetext{
28 Ibid., Part 3.

${ }^{29}$ Ibid., Part 2b.

30 Ibid.

${ }^{31}$ lbid., Part 4.
} 
fairly easily restated to say that 'without evil, we could not recognize good.' In another similar example, Koch claims that:

the Christian church without Israel would be in danger of losing its locus in the history of salvation and degenerating into an ultimately unhistorical gnosis. By the same token, Jews could with regard to the Abrahamic covenant arrive at the insight that Israel without the church would be in danger of remaining too particularist. In this fundamental sense Israel and the church remain bound up with one another according to the covenant and interdependent on one another. ${ }^{32}$

Moving full circle, it is interesting that the Cardinal employs the critique of Judaism that was levelled by German Protestant intellectuals like Hegel who argued that even Islam had surpassed Judaism in overcoming particularism.

As Koch moves to propose topics that are critical to the agenda of future Jewish-Christian dialogue, he highlights two items in particular. First, he states that"

one cannot simply overlook the fact that the Christian doctrine of the Trinity signals without a doubt the most prominent difference between Judaism and Christianity and must therefore remain an essential topic of conversation in Jewish-Christian dialogue. ${ }^{33}$

It is not clear from this statement why the Trinity is essential, aside from the fact that it represents a significant difference between the two, and it begs the question of what the Jewish people might gain from such a conversation. Would dialogue that centered on the Trinity be an attempt to persuade Judaism of its truth or reality or necessity? In addition, is the Trinity an issue that the Jewish people see as an essential issue in dialogue? Would it, for example, be considered more important than discussions of the role of the land of Israel in Jewish life, theology, and tradition, a topic which Cardinal Koch does not address? A second item, which Koch describes as a "pointer for future dialogue between Jews and Christian" is the cross. ${ }^{34}$ Even though, states Koch,

the cross of Jesus Christ has again and again in the course of Christian history been misused as an anti-sign of hostility and hatred towards the Jews by condemning them as deicides, Christians today have every reason and a strict obligation to proclaim and testify also to the Jews the cross of Jesus as a sacrament of reconciliation. ${ }^{35}$

With such a long and fraught history, it is hard to imagine that the cross could ever become, at least in the foreseeable future, a sacrament of reconciliation for Jews and Christians. Given this reality, it hardly seems just to both "proclaim and testify" to Jews this sense of the cross. Can reconciliation be truly achieved through the one-sided insistence on the symbol of that reconciliation?

\footnotetext{
${ }^{32}$ Ibid., Part 2b.

33 Ibid., Part 3.

34 Ibid., Part 4.

35 Ibid.
} 


\section{Conclusion}

Recounting a history of mutual hostility and shared victimhood, Koch tends to diminish Christianity's responsibility for the suffering of the Jewish people. This allows him to frame the current relationship between Christians and Jews as one of mutual obligation toward as well as need for the other. But is this really the case? In the theological dimension he tends to privilege the position and role of Christianity with respect to Judaism. His case is much more convincing as to why Christians need the Jews in that he says that together they must together witness to the world that there is one covenant, that Jews must remain the first proprietors of scripture, and that Jews must continue to exist because the integrity of Christianity is threatened without them. Ultimately, this particular framing can give rise to the sense that Christianity needs Judaism to serve for them as a continuous and indefinite praeparatio evangelica, resulting in a kind of theological utilitarianism. 